\title{
Triamcinolone Acetonide and 5-Fluorouracil Intralesional Combination Injection in Keloid Treatment
}

\author{
Jono Hadi Agusni, Eva Krishna Sutedja, Franky Chandra \\ Department of Dermatology and Venereology, Faculty of Medicine, Universitas Padjdajaran-Dr. Hasan Sadikin \\ General Hospital
}

\begin{tabular}{|c|c|}
\hline \multirow[t]{3}{*}{ Abstract } & $\begin{array}{l}\text { Objective: To evaluate the effectiveness of steroid and 5-fluorouracil (5-FU) } \\
\text { injection combination for keloid management. }\end{array}$ \\
\hline & $\begin{array}{l}\text { Methods: A 22-year-old female patient was presented with recurrent skin } \\
\text { lesions. The skin lesions first appeared } 10 \text { years prior to consultation, had } \\
\text { been surgically excised, and were given triamcinolone acetonide injection. } \\
\text { However, no improvement was observed. A decision was made to use } \\
\text { and evaluate treatment using an intralesional } 4 \mathrm{mg}(0.1 \mathrm{ml} \text { of } 40 \mathrm{mg} / \mathrm{ml}) \\
\text { triamcinolone acetonide and } 45 \mathrm{mg}(0.9 \mathrm{ml} \text { of } 50 \mathrm{mg} / \mathrm{ml}) 5 \text {-FU injection } \\
\text { combination for } 5 \text { weeks. }\end{array}$ \\
\hline & $\begin{array}{l}\text { Results: Clinical improvements were observed in the third week as the } \\
\text { lesions softened and pruritic sensation dinimished. At the end of the fifth } \\
\text { week, improvements in the form of keloid lesion flattening and size reduction } \\
\text { were observed. }\end{array}$ \\
\hline $\begin{array}{l}\text { Received: } \\
\text { May 31, } 2016\end{array}$ & $\begin{array}{l}\text { Conclusions: Intralesional injection using a combination of triamcinolone } \\
\text { acetonide and 5-fluorouracil is effective for keloid lesion treatment. }\end{array}$ \\
\hline $\begin{array}{l}\text { Revised: } \\
\text { October } 25,2016\end{array}$ & $\begin{array}{l}\text { Keywords: 5-fluorouracil, intralesional injection, keloid, triamcinolone } \\
\text { acetonide }\end{array}$ \\
\hline $\begin{array}{l}\text { Accepted: } \\
\text { February 27, } 2017\end{array}$ & $\begin{array}{l}\text { pISSN: 2302-1381; eISSN: 2338-4506; http://doi.org/10.15850/ijihs.v5n1.959 } \\
\text { IJIHS. 2017;5(1):36-41 }\end{array}$ \\
\hline
\end{tabular}

\section{Introduction}

Keloid is resulted from an abnormal wound healing process of injured skin that is marked by uncontrolled dermal as well as subcutaneous collagen synthesis and also deposition beyond the original site of injury. Keloid does not regress spontaneously and has the tendency to recur after excision..$^{1-5}$ The exact etiology is not understood but genetic predisposition to keloids has long been suggested due to the fact that patients with keloids often report a positive family history. ${ }^{4-8}$

Until recently, keloid has been a challenge for dermatologists because of its recurrency and inadequate responses to the treatment modalities including drugs, silicon gel sheet dressing, compression therapy, excision, and

\section{Correspondence:}

Franky Chandra, Department of Dermatology and Venereology, Faculty of Medicine, Universitas Padjdajaran-Dr. Hasan Sadikin General Hospital

Jl. Pasteur No. 38, Bandung, Indonesia

e-mail: franky_chandra_87@yahoo.co.id cryoteraphy. ${ }^{1,3}$ Until currently, intralesional injection of corticosteroid has always been the first line treatment for keloids, with triamcinolone acetonide (TA) as the most common agent. ${ }^{4,6}$ Unfortunately, old keloids do not respond well to steroids. There are reports documenting a successful use of steroid and 5-fluorouracil (5-FU) injection combination for keloid that have been published. ${ }^{7}$ This article will describe a case report of a 22-yearold woman with keloid who was treated with intralesional TA and 5-FU combination.

\section{Case}

A 22-year-old woman who complained about the presence of red purple and pruritic tumors on her neck, shoulder, and chest visited Tumor and Dermatosurgery Outpatient Clinic of Dr. Hasan Sadikin General Hospital, Bandung, Indonesia. The first complaint emerged about 10 years ago as lenticular tumors on neck, shoulder, and chest started as acne scars. 


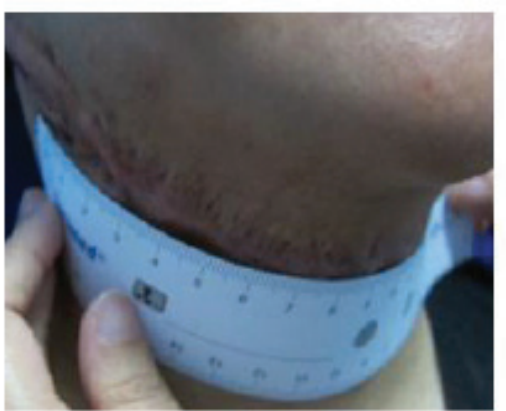

a. Neck

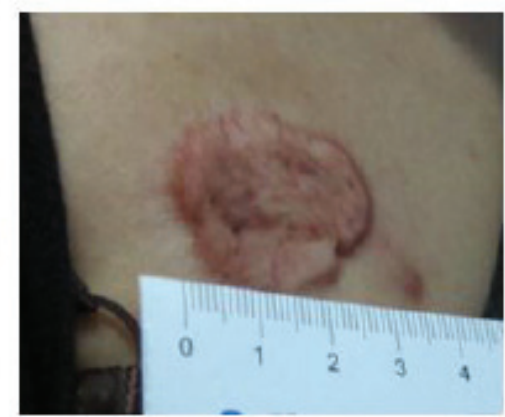

b.Chest

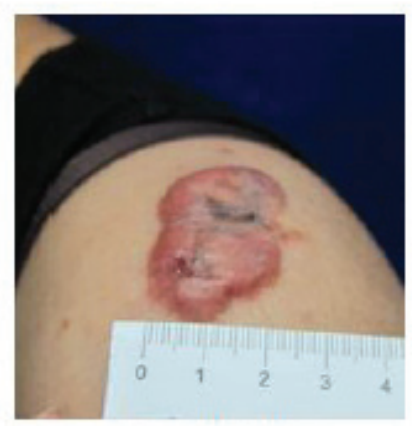

c. Left Shoulder

Fig. 1 Patient's Original Keloid Lesions. a) 13 x 2.5 x 0.7 cm, Irregular Keloid Lesion with Hyperpigmentation. b) $3.3 \times 2.5$ x $0.1 \mathrm{~cm}$, Irregular Purplish Red Keloid Lesion with Telangiectasia. c) $4.2 \times 2.2 \times 0.2 \mathrm{~cm}$, Irregular Hyperpigmented Purplish Red Keloid

Two years later, the lesions extended over the original border and the patient underwent excision by a surgeon. Three months later, the tumor relapsed on the operation scar site, but patient did not seek any treatment. Howover, the lesions enlarged and became itchy, that the patient decided to visit our clinic and was given TA $0.1 \mathrm{ml} / \mathrm{cm} 2(10 \mathrm{mg} / \mathrm{ml})$ injections every 2 weeks. Due to the lack of improvement after 3 months, the patient was suggested to go on surgery, but she refused.

On physical examination, a $13 \times 2.5 \times 0.7$ $\mathrm{cm}$, solitary, irregular form, clear border, bulging, and dry hyperpigmented tumor lesion was found on the anterior surface of neck. On the left shoulder, a $4.2 \times 2.2 \times 0.2 \mathrm{~cm}$, solitary, irregular form, clear border, bulging, and dry hyperpigmented purplish red tumor was observed. On the chest, a $3.3 \times 2.5 \times 0.1 \mathrm{~cm}$, solitary, irregular form, clear border, bulging, and dry purplish red tumor was discovered with telangiectasia (Fig. 1). Patient's final diagnosis was keloid on neck, chest and left shoulder.

In this case, lesions were treated with intralesional combination of $4 \mathrm{mg}(0.1 \mathrm{ml}$ of 40 $\mathrm{mg} / \mathrm{mL}) \mathrm{TA}$ and $45 \mathrm{mg}(0.9 \mathrm{ml}$ of $50 \mathrm{mg} / \mathrm{mL})$ 5-FU injection for 5 weeks. The procedure was started with the provision of local anesthesia using lidocain 1\%. Four miligrams TA and 45 mg 5-FU combination injections were given within $1 \mathrm{~cm}$ distance until the tissue bleached. After two weeks, clinical improvements were seen in the form of decreased pruritus, softened and flattened keloid on her neck, and reduced keloid size on the shoulder. After five injection series, lesion on the neck looked flatter and lesion on chest was minimized. In this case, ulceration at the injection sites developed after the first injection and could be managed with topical application of gentamycin $0.1 \%$ cream, twice a day.

\section{Discussion}

Keloid may appear as pink to purple-colour tumor, with glistening surface, accompanied by hyperpigmentation or telangiectasia and, occassionally, subjective symptoms of pain or pruritus. ${ }^{7,9}$ In this case, patient's history and physical examination supported keloid diagnosis because the lesssion showed a purplish-pink, shiny, and clear margin keloid lesion.

The ultimate goal of hypertrophic scar and keloid management is to prevent function impairment and maintain an appearance thati is cosmetically acceptable. ${ }^{10}$ For this specific patient, the treatment was sought because the keloid was enlarging, cosmetically iritating, and itchy. Intralesional corticosteroid injection softens and flattens keloids by decreasing fibroblast proliferation, collagen synthesis, glycosaminoglycan synthesis, and suppressing pro-inflammatory mediators. ${ }^{1,5}$ The most commonly used corticosteroid for keloid is $10-40 \mathrm{mg} / \mathrm{mL}$ triamcinolone acetonide injection that is administered intralesionally at 2-3-week intervals. ${ }^{1}$ Response to therapy should be observed within three months, and injections should be discontinued when 


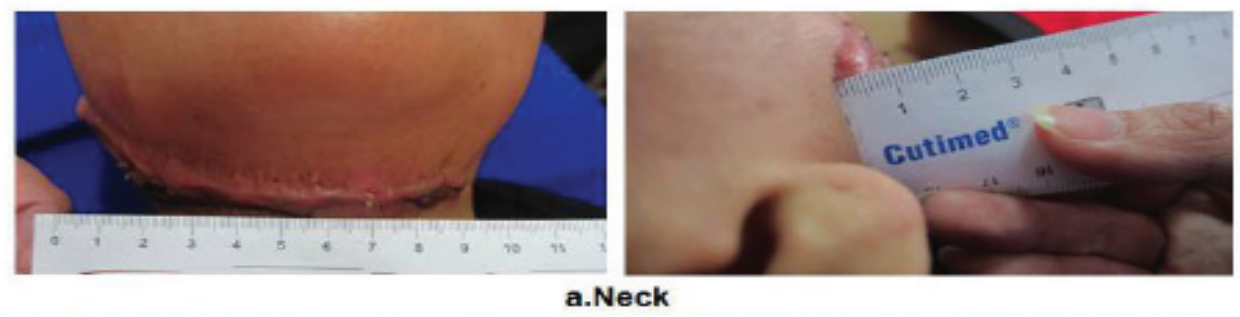

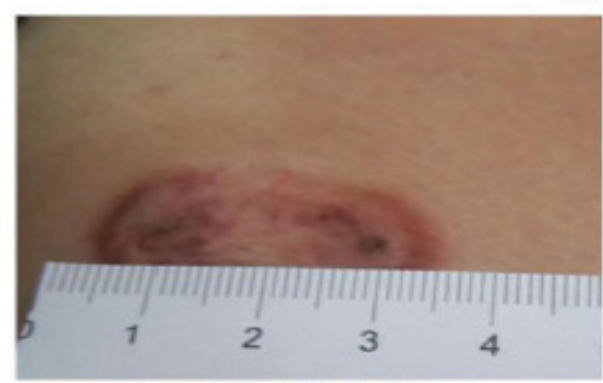

b.Right Chest

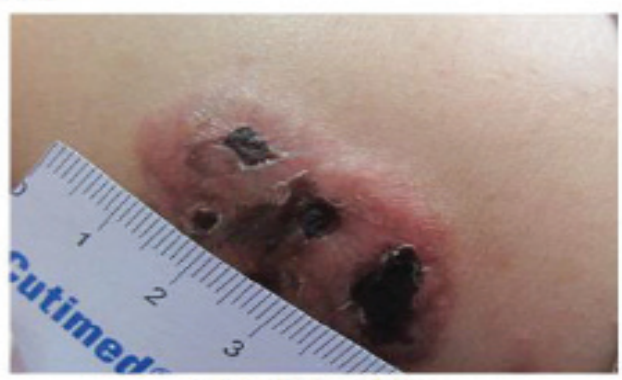

c.Left shoulder

Fig. 2 Keloid Lesions on the Third Intralesional Injection. a) $13 \times 2.5 \times 0.5 \mathrm{~cm}$ b) $3.3 \times 2.5 \times 0.1 \mathrm{~cm}$. c) $4 \times 2.2 \times 0.2 \mathrm{~cm}$. Note the Hemorrhagic Crusts on Keloid Lesions on Neck and Left Shoulder after Injection. Patient Admitted Some Improvements such as Diminishing Itch and Softening of Lesions
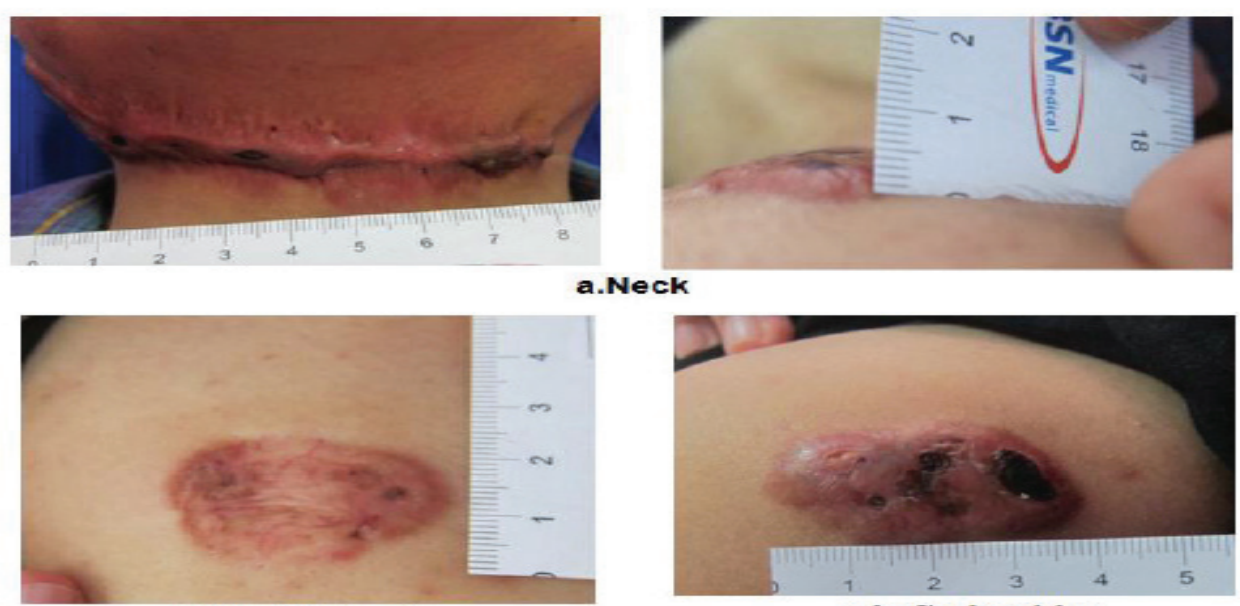

b.Right Chest

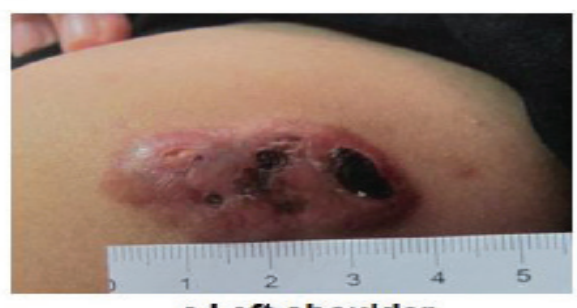

Fig. 3 Keloid Lesions on the Fourth Intralesional Injection. a) $13 \times 2.5 \times 0.4 \mathrm{~cm}$. b) 3.3 x $2.5 \times 0.1 \mathrm{~cm}$. c) $4 \times 2.2 \times 0.2 \mathrm{~cm}$

the scar is stable, surgical intervention is indispensable, or if side effects such as tissue atrophy, hypopigmentation, or telangiectasia develop. ${ }^{5}$

The patient in the study had been given a 3 month intralesional TA before deciding to discontinue the treatment due to the lack of improvement. Furthermore, keloid lesion on her neck was highly risk for contracture, thus she was consulted to be operated. The most common indications for keloids surgery are large lesions that are unlikely to be completely managed by medical therapy in a reasonable time frame and keloid scar contractures that 
hamper musculoskeletal function. ${ }^{10,11}$ In this case, patient had been advised by Plastic Surgery Department to have excision, but she had refused. Patient agreed to get intralesional TA and 5-FU injection combination after informed consent was given.

The biological basis of keloid formation lies on the substantial proliferation, apoptosis inhibition of fibroblastsand imbalance between collagen synthesis and degradation. ${ }^{12,13}$ Keloid fibroblasts are considered to proliferate more rapidly, with oversecretion of type I collagen fibers and high expression levels of vascular endothelial growth factor, transforming growth factor- $\beta 1 \beta 2$ and platelet-derived growth factor- $\alpha{ }^{12}$ TGF- $\beta$ has been implicated in the collagen synthesis 1 by increasing the effect of epidermal growth factor (EGF) in fibroblast population, which stimulates epithel differentiation and initiates DNA and RNA synthesis. ${ }^{8}$

Intralesional 5-FU works by inhibiting fibroblast proliferation, interrupting both DNA and RNA synthesis as well as inhibiting TGF$\beta$-induced expression of the type I collagen gene in human fibroblasts. ${ }^{3,5,14}$ 5-fluorouracil acts as an alternative therapeutic agent for patients who have not responded well to corticosteroids. ${ }^{1}$

5-fluorouracil is administered once every one or two weeks, up to thrice a week, adjusted according to the extent of the lesions, but the dosage given should not exceed $100 \mathrm{mg} /$ session $(2 \mathrm{~mL})$. The solution is injected into the central aspect of scar tissue, until slight blanching is clinically visible, usually $0.05 \mathrm{cc}$ or less/injection site, approximately $1 \mathrm{~cm}$ apart. ${ }^{1}$ 5-FU dosage should be adjusted in patients with liver dysfunction. ${ }^{14}$ Contraindications to 5-FU include pregnancy, breastfeeding allergy, bone marrow depression, and severe intercurrent infection. ${ }^{1,15}$ The most common side effects of 5-FU injection include pain or discomfort, ulceration, burning sensations, and hyperpigmentation at the injection site. ${ }^{1,7,15}$ Addition of $0.1 \mathrm{ml}$ of TA ( $40 \mathrm{mg} / \mathrm{ml}$ ) to $0.9 \mathrm{ml}$ of $5-\mathrm{FU}(50 \mathrm{mg} / \mathrm{ml})$ helps to reduce the pain and also the inflammation. ${ }^{3}$

Khan et $a .^{6}{ }^{6}$ has compared the use of TA injection as a monotherapy to $\mathrm{TA}$ and 5-FU injection combination for 150 patients with keloid and hypertrophic scars, who were divided into two experimental groups. In this study, eight injections were given in weekly

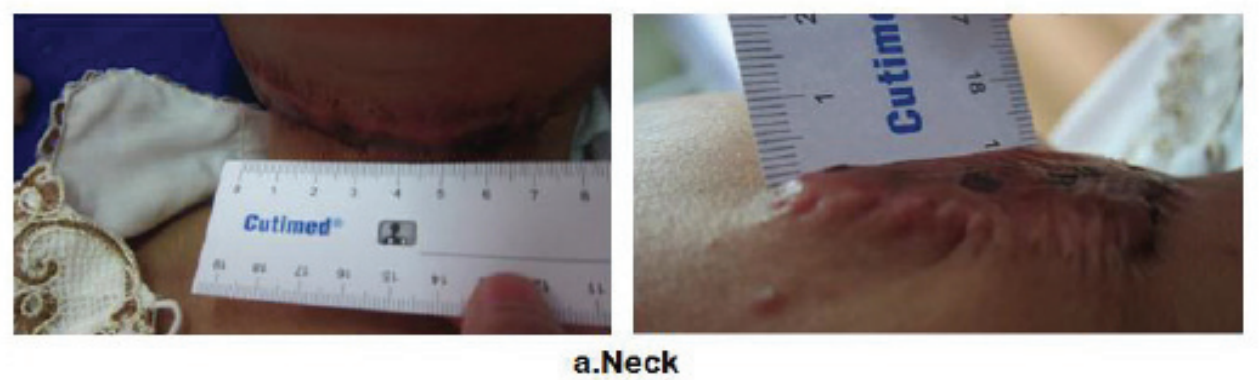

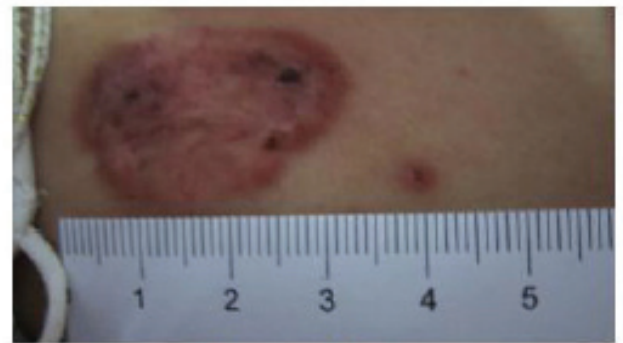

b.Right Chest

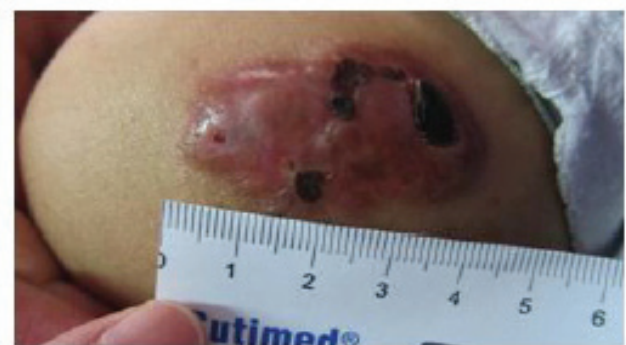

c.Left shoulder

Fig. 4 Keloid Lesions on the Fifth Intralesional Injection. a) $13 \times 2.5 \times 0.4 \mathrm{~cm}$. b) $3 \times 2.5$ x $0.1 \mathrm{~cm}$. c) $4 \times 2.2 \times 0.2 \mathrm{~cm}$. Patient Admitted Improvements as Flattening and Size Reduction of the Lesions 
interval. The group receiving combination of 4 $\mathrm{mg}$ TA and $45 \mathrm{mg} 5-\mathrm{FU}$, demonstrated good results (lesion height reduction: $50-75 \%$ ) and excellent results (lesion height reduction: 75$100 \%)$ in 63 patients (84\%) while in the group receiving $10 \mathrm{mg}$ TA injection as monotherapy, good and excellent results were seen in 51 patients $(68 \%)$.

According to this patient's history, physical, and laboratory examination, she had no contraindication towards 5-FU administration and did not need any dosage adjustment. Patient was given $4 \mathrm{mg}$ TA and $45 \mathrm{mg}$ 5-FU injection combination therapy once a week. Lidocaine injection was given before therapy administration to minimize the pain. Every injection was separated by $1 \mathrm{~cm}$ distance. Gentamycin $0.1 \%$ cream was applied after the procedure and patient was requested to apply it twice a day if ulceration developed.

The superficial ulcerations at the injection

\section{References}

1. Pratchyapruit W, Vashrangsi N. A new therapeutic modality intralesional 5-fluorouracil in the treatment of keloids and hypertrophic scar. Inst Dermatol Ass. 2012;13(9):157-63.

2. Kelly AP. Update on the management of keloids. Semin Cutan Med Surg. 2009;28(2):71-6.

3. Sharma S, Bassi R, Gupta A. Treatment of small keloids with intralesional 5-fluorouracil alone vs intralesional triamcinolone acetonide with 5-fluorouracil. J Pak Assoc Dermatol. 2012;22(1):35-40.

4. Guimarães CO, Parada MB, Bagatin E. Keloid treatment:comparative intralesional injections of 5-fluorouracil, corticosteroid and 5-fluorouracil combined with corticosteroid. Surg Cosmet Dermatol. 2011;3(1):60-2.

5. Wolfram D, Tzankov A, Pulzi P, Piza-Katzer H. Hypertrophic scars and keloids-A review of their pathophysiology, risk factors, and therapeutic management. Dermatol Surg. 2009;35(2):171-81.

6. Khan MA, Bashir MM, Khan FA. Intralesional triamcinolone alone and in combination with 5-fluorouracil for the treatment of keloid and hypertrophic scars. J Pak Med Assoc. 2014;64(9):1003-7.

7. Gauglitz GG, Korting HC, Pavicic T, Ruzicka T, Jeschke MG. Hypertrophic scarring and keloids: Pathomechanisms and current and sites may be observed soon after the first 2-3 injection sessions and may heal with the use of topical antibiotics. ${ }^{2}$ The hyperpigmentation typically resolves spontaneously after three months. ${ }^{15}$ In this case, ulceration developed after the first injection and could be managed with topical application of gentamycin $0.1 \%$ cream, twice a day.

Response of therapy commonly needs five to ten injection sessions. The first subjective symptoms of response are decreased pain and pruritus followed by softened and flattened scar and decreased erythema. ${ }^{4}$ In this case, the patient felt symptom improvements as decreased pruritus and softened keloid lesion after two injections. On examination, keloid on her neck become flattened and the other on shoulder reduced in size. After five injection series, lesion on the neck looked more flat and lesion on chest was minimized (Fig. 2-6).

emerging treatment strategies. Mol Med. 2011;17(1):113-25.

8. Gauglitz GG. Management of keloids and hypertrophic scars:current and emerging options. Clin Cosmet Investig Dermatol. 2013;6(1):103-14.

9. Chike-Obi CJ, Cole PD, Brissett AE. Keloids: Pathogenesis, clinical features, and management. Semin Plast Surg. 2009;23(3):178-84.

10. Vivas AC, Tang JC, Maderal AD, Viera MH. Hypertrophic scars and keloids, part 1:conventional treatments. Cosmet Dermatol. 2012;25(3):309-16.

11. Edriss AS, Smrcka V. Therapy of keloid and hypertrophic scars:a review. Eur J Plast Surg. 2011;34(5):425-36.

12. Dong $\mathrm{X}$, Mao S, Wen $\mathrm{H}$. Upregulation of proinfammatory genes in skin lesions may be the cause of keloid formation. Biomed Rep. 2013;1(6):833-6.

13. Gupta S, Sharma VK. Standard guidelines of care: keloids and hypertrophic scars. Indian J Dermatol Venereol Leprol. 2011;77(1):94-100.

14. Darougheh A, Asilian A, Shariati F. Intralesional triamcinolone alone or in combination with 5-fluorouracil for the treatment of keloid and hypertrophic scars. Clin Exp Dermatol. 2009;34(1):219-23.

15. Kranendonk S, Obagi S. An algorithmic approach 
to hypertrophic scars and keloids:maximizing nonsurgical options. J Cosmet Dermatol. 2011;24(1):28-39.

16. Indrayati H, Agusni JH, Soedarwoto A,
Kartamihardja AHS. Comparison of the effectiveness of phosphorus 32 application and $10 \mathrm{mg} / \mathrm{cc}$ triamcinolone acetonide intralesional injection on keloid. IJIHS. 2016;4(1):26-31. 